\title{
УДК 811.161.1’373.611
}

БОНДАРЕВА Ольга - аспірантка кафедри світової літератури та російського мовознавства, Луганський національний університет імені Тараса Шевченка, площа Гоголя, 1, Старобільськ, Луганська область, 92703, Украӥна (bondarevaolya@ukr.net)

ORCID: https://orcid.org/0000-0001-8114-1099

DOI: https://doi.org/10.24919/2522-4565.2021.46.2

Бібліографічний опис статті: Бондарєва, О. (2021). Номінатема комплексного зразка та особливості ії втілення у мовленні (на матеріалі російської мови). Проблеми гуманітарних наук: збірник наукових пращьь Дрогобищького державного педагогічного університету імені Івана Франка. Серія «Філологія», 46, 17-23, doi: https://doi.org/10.24919/2522-4565.2021.46.2

\section{НОМІНАТЕМА КОМПЛЕКСНОГО ЗРАЗКА ТА ОСОБЛИВОСТІ ЇЇ ВТІЛЕННЯ У МОВЛЕННІ (НА МАТЕРІАЛІ РОСІЙСЬКОЇ МОВИ)}

Анотація. Питання про визначення мовних одиниць постає надважливим у лінгвістичній теорії. Комплексний опис основної одиниці мови виявляє залежність від вибору підходу до ідентифікачї мовних інваріантів. У статті зазначені дві парадигми його вирімення - словоцентричну та несловоцентричну. Традиційну лінгвістику характеризує тенденція до виділення словосполучень та інших одиниць разом зі словами як таких, щзо мають семантичну, а значить і номінативну иілісність. Базовими різновидами номінативних одиниць уважають наслідки мовної номінації (слова-синтагми, глоси прості й комплексні, модифікації відповідних номінатем), а базовою одиницею мовної номінації - номінатему.

У статті детально розглянуто номінатеми-словосполучення, тобто номінатеми комплексного зразка та їхні структурні різновиди. До них віднесено всі семантично тотожні одиниці, а саме: ідіоматизоване словосполучення, тобто колокацію; фразеологізоване словосполучення; сполуку повнозначного слова зі службовим та аналітичні лексико-граматичні варіанти; універбалізований еквівалент словосполучення, тобто слово, щзо з'явилося внаслідок вербального модифікування словосполучення і є тотожним йому в лексико-граматичній системі координат. Метою статті є визначення параметрів ідентифікації номінатем комплексного зразка, дослідження иляхів реалізації основної номінативної одиниці та особливостей втілення номінатеми комплексного типу в мовленні та тексті. Методи та методики дослідження. У дослідженні використано низку методів, щзо дали змогу максимально об'єктивно вивчити проблему й дійти певних висновків. Зокрема, метод суцільної вибірки застосовано для накопичення фактичного матеріалу, а методику дистрибутивного аналізу - для диференціювання понять. Висновки. Основною номінативною одиницею визнано певний інваріант слово чи словосполучення - на підставі критеріїв номінативності та семантико-граматичної тотожності всіх його реалізацій.

Ключові слова: номінатема, варіант, інваріант, словосполучення, еліптема, композит.

BONDARIEVA Olga - Postgraduate Student at the Department of World Literature and Russian Linguistics, Luhansk Taras Shevchenko National University, 1 Gogol Square, Starobilsk, Luhansk region, 92703, Ukraine (bondarevaolya@ukr.net)

ORCID: https://orcid.org/0000-0001-8114-1099

DOI: https://doi.org/10.24919/2522-4565.2021.46.2

To cite this article: Bondarieva, O. (2021). Nominatema kompleksnoho zrazka ta osoblyvosti yiyi vtilennya u movlenni (na materiali rosiys'koyi movy) [Nominatheme of complex type and features of its implementation in speech (on the materials of the russian language)]. Problemy humanitarnych nauk: zbirnyk naukovych prats Drohobytskoho derzhavnoho pedahohichnoho universytetu imeni Ivana Franka. Seriia "Filolohiia" - Problems of Humanities. «Philology» Series: a collection of scientific articles of the Drohobych Ivan Franko State Pedagogical University, 46, 17-23, doi: https://doi.org/10.24919/2522-4565.2021.46.2 [in Ukrainian].

(C) Бондарєва Ольга, 2021 


\section{NOMINATHEME OF A COMPLEX TYPE AND FEATURES OF ITS IMPLEMENTATION IN SPEECH (ON THE MATERIAL OF THE RUSSIAN LANGUAGE)}

Summary. The question of defining language units is of paramount importance in linguistic theory. A comprehensive description of the basic unit of language reveals the dependence on the choice of approach to the identification of language invariants. The article identifies two paradigms for its solution - word-centric and non-word-centric. Traditional linguistics is characterized by the tendency to distinguish word-combinations and other units together with words as having semantic, and hence nominative integrity. The basic types of nominative units are considered to be the consequences of linguistic nomination (words-syntagms, glosses, simple and complex modifications of the corresponding nominatheme), and the basic unit of linguistic nomination is the nominatheme.

The article considers in detail the nominathemes-word-combination, ie the nominathemes of the complex type and their structural varieties. These include all semantically identical units, namely: idiomatized word-combination, ie colocation; phraseologized word-combination; combination of a full word with office and analytical lexical and grammatical variants; the univerbalized equivalent of a word-combination, ie the word that appeared as a result of verbal modification of the wordcombination, is identical to it in the lexical-grammatical coordinate system. The purpose of the article is to determine the parameters of identification of nominathemes of the complex type, research of ways of realization of the basic nominative unit and features of embodiment of the nominatheme of complex type in speech and text. Research methods and techniques. The study used a number of methods that allowed to study the problem as objectively as possible and draw certain conclusions. In particular, the method of continuous sampling is used to accumulate factual material, and the method of distributive analysis - to differentiate concepts. Conclusions. The main nominative unit is a certain invariant - a word or word-combination - on the basis of the criteria of nominativeness and semantic-grammatical identity of all its implementations.

Key words: nominatheme, variant, invariant, word combination, ellipthema, composite.

Постановка проблеми. Питання про визначення мовних одиниць постає надважливим у лінгвістичній галузі. У контексті комплексного опису основної одиниці мови значущою постає 㣙 залежність від вибору підходу до ідентифікації мовних інваріантів. У статті зазначено дві парадигми вирішення зазначеного питання - словоцентричну й несловоцентричну. Остання дає змогу провести різнобічний аналіз мовних одиниць та всього комплексу їх утілень у мовленні.

Аналіз останніх досліджень і публікацій. Стосовно проблеми основної одиниці номінації висловлювалися Ш. Баллі, В.А. Звегинцев, Л. Блумфілд, В.М. Жирмунський, І.О. Бодуен де Куртене, А. Мартіне, Й. Вахек, С.Д. Кацнельсон, Ф. де Соссюр, Ж. Вандрієс, А. Фрай. У їхніх працях запро-

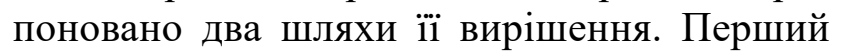
шлях В.М. Алпатов умовно назвав словоцентричним (Алпатов, 1982, с. 66-74). Основоположником другого способу (несловоцентричного) вважають I.О. Бодуена де Куртене. Сутність цього підходу дещо пізніше розкрив Л. Блумфілд, запропонувавши позначати одиницю мови терміном форми (Блумфильд, 1968). При цьому мінімальною формою в його концепції постає морфема. Далі послідовно стали виділяти слово, словосполучення і речення.

Більш докладно дослідженням номінатеми в ономасіологічному аспекті займається Н.В. Дьячок (Дьячок, 2017).

Метою дослідження $\epsilon$ визначення параметрів ідентифікації номінатем комплексного зразка, що сприяє найповнішому опису семантико-формальних характеристик номінатем як мовних інваріантів. Досягнення мети зумовлене вирішенням низки завдань: 1) визначення мовного інваріанта; 2) аналіз його мовленнєвої структури; 3) створення й опис моделей модифікування номінатеми. Предметом дослідження є низка номінатем, способи модифікації яких втілено у комплексі мовленнєвих і текстових репрезентацій.

\section{Завдання:}

1) описати два підходи до вивчення основної мовної одиниці;

2) зазначити критерії тотожності досліджуваного інваріанта; 
3) представити структурні різновиди номінатеми 3 домінантою-словом;

4) представити структурні різновиди номінатеми $з$ домінантою-словосполученням;

5) структурувати типи комплексної реалізації інваріанта 3 домінантою-словосполученням.

Виклад матеріалу. У межах традиційної словоцентричної парадигми головною номінативною одиницею є слово, тому «аналіз починається 3 виділення слів, від яких відштовхуються за розгляду як менших одиниць (морфем), так і більших (словосполучень, часом речень) одиниць мови» (Алпатов, 1982, c. 66-74).

Проявом несловоцентричного підходу $\epsilon$ й уявлення про номінативність словосполучень, сутність якого виклав А.П. Загнітко: «Основна функція словосполучення - номінативна» (Загнітко, 2003, с. 53). Згідно з таким розумінням «комбінація слів і словосполучення репрезентує з'єднання деяких окремих значень-сигніфікатів, внаслідок чого утворюється нова номінативна одиниця, ідентифікація й розуміння якої грунтується на адекватному відтворенні деякої реальної єдності предметів, явищ та їхніх властивостей (поєднання предмета й ознаки, поєднання предметів, поєднання дій тощо)» (Уфимцева, Серебреникова, 1977, с. 122).

У традиційній лінгвістиці можна простежити тенденцію до виділення словосполучень та інших одиниць, включно зі словами, як таких, що мають семантичну, а значить і номінативну цілісність. Отже, ми дійшли висновку, що слово $є$ не так базовою номінативною одиницею, як одним із формальних іiі різновидів. Визначення основної одиниці мови (або основної номінативної одиниці) пов'язане з виділенням одиниці, яка зосереджує в собі основну - номінативну - функцію.

B.I. Теркулов зазначає: «Номінативний інваріант $є$ абстрактною одиницею, узагальненою від всіх її реалізацій, що тією чи тією мірою присутня в низці однорідних конкретних одиниць, що мають статус ії варіантів чи дублетів» (Теркулов, 2007, с. 47). Інваріант завжди представлений своїми варіантами.

Критерії тотожності досліджуваного інваріанта можна представити так.
1. Номінатема як мовна одиниця здатна містити безліч диференційних ознак, що не порушують уявлень про її єдність.

2. Номінатема реально функціонує в мовленні в одній зі своїх модифікацій-дублетів, тому модифікування номінатеми $є$ формою їі буття.

3. Тотожність номінатеми передбачає дублетне модифікування, яке полягає в повній семантичній ідентичності порівнюваних одиниць. За такого дублетного модифікування дублети завжди збігаються як в лексичній площині, так і в граматичній.

4. Існує семантико-граматична цілісність номінатеми, тобто сукупність потенційно властивих їй текстових і мовленнєвих реалізацій.

Зазначені критерії дають підстави до виділення номінатем 3 домінантою-словом (тобто тих, де первинна номінація відбулася словом) та номінатем 3 домінантою-словосполученням (тих, де первинна номінація відбулася словосполученням). Структурними різновидами номінатеми 3 домінантою-словом уважаємо всі семантично тотожні одиниці, ідентифіковані на рівні слова, як-от:

1) безпосередньо слово у всіх контекстах його вживання з семантикою, що еквівалентна йому самому (наприклад, девушка запрыгнула в автомобиль, де слово автомобиль є еквівалентним самому собі, позаяк його семантику реалізовано без залучення семантики інших слів $з$ контексту);

2) поєднання повнозначного слова 3 прийменником (автомобиль - в автомобиль, оскільки в цьому випадку спостерігаємо тотожність семантики іменника й прийменниково-іменникової сполуки);

3) слово, поширене залежною від повнозначної лексемою, яка виконує функцію семного конкретизатора (иикарный автомобиль, де прикметник шикарный виконує функцію семного конкретизатора, тобто звужує, а значить і конкретизує семантику іменника автомобиль).

Структурними різновидами номінатем 3 домінантою-словосполученням є всі семантично тотожні одиниці, ідентифіковані на рівні словосполучення, а саме:

1) ідіоматизоване словосполучення, тобто колокація, яку розуміють як «лексико-се- 
мантичний тип словосполучення, що за своєю внутрішньою семантичною структурою перебуває між вільним та фразеологічним сполученням» (Jackson, 1995, с. 97) (жевательная резинка, железная дорога, грудная жаба);

2) фразеологічний зворот, утворення якого зумовило ідіоматизоване словосполучення i який $є$ постійним і відтворюваним вживанням «вільного сполучення слів не в прямому, а в узагальненому, образно-переносному значенні» (Шанский, 1996, с. 92) (красная строка, сизифов труд, темна вода во облачех);

3) сполучення зі службовим словом (со знаменитой певицей) та аналітичні лексикограматичні варіанти (красивая знаменитая певица);

4) універбалізований еквівалент словосполучення, тобто слово, що з'явилося внаслідок вербального модифікування словосполучення, $є$ тотожним словосполученню в лексико-граматичній системі координат, а значить, демонструє тотожність лексичного та граматичного значень і синтаксичної функції.

Четвертий різновид номінатеми має таку типологію.

1. Вербальна реалізація номінатеми, що 3'явилася внаслідок еліптичної трансформації словосполучення в слово: а) еліптема залежне слово; б) еліптема - головне слово; в) еліптичний універб.

2. Вербальна реалізація номінатеми, що з'явилася внаслідок композитної компресії словосполучення: а) абревіатура; б) формальний компресив; в) компресивний універб тощо.

Отже, номінативною одиницею мови не можна вважати лише слово, як стверджують прихильники словоцентризму. Таку одиницю доцільно розглядати як певний інваріант, здатний містити характеристики слова та його форм або характеристики словосполучення та його форм. Найголовнішими чинниками визначення мовного інваріанта постають номінативність та семантико-граматична тотожність всіх його форм різної структури.

Н.В. Дьячок (Дьячок, 2017, с. 93-98) виокремила шість структурних типів мовних інваріантів, що комплексно реалізуються в усному та писемному мовленні:
1) словосполучення + абревіатура + еліптичний універб, наприклад: административная страница - админстраница - админка;

2) словосполучення + композит + еліптичний універб, наприклад: ливневый сток ливнесток-ливневка;

3) словосполучення + словосполучення юкстапозитно-абревіатурного зразка + еліптичний універб, наприклад: микроволновая печь - МВ-печь - микроволнушка;

4) словосполучення + еліптичний універб + еліптема (головне слово) + композит, наприклад: электрическая печь-электричкапечь - электропечь;

$5)$ словосполучення + еліптичний універб + еліптема (залежне слово), наприклад: борзая собака - борзюк-борзая;

6) словосполучення + композит абревіатурного зразка + абревіатура + еліптичний універб, наприклад: заграничный паспорт загранпаспорт - загран-загранник.

Ми додали до цього переліку ще вісім типів комплексної реалізації інваріанта з домінантою-словосполученням.

1. Номінатема на зразок «словосполучення + композит абревіатурного зразка + еліптичний універб + еліптема (головне слово) + абревіатура», що репрезентована такою структурою:

\section{Nom}

(системный
администратор)

WCom

(системный администратор)

\section{CompAbbr \\ (сисадмин)}

\section{$\mathbf{U}$ \\ (системник) \\ EI \\ (администратор)}

\section{Abbr \\ (админ),}

де Nom - номінатема 3 домінантою-словосполученням, WCom - iï модифікація-словосполучення, CompAbbr - iї модифікація-композит абревіатурного зразка, $\mathbf{U}$ - iї модифікаціяуніверб, El - іï модифікація-еліптема (головне слово), Abbr - iї модифікація-абревіатура.

2. Номінатема на зразок «словосполучення + композит абревіатурного зразка + еліптема (головне слово)», що репрезентована такою структурою: 


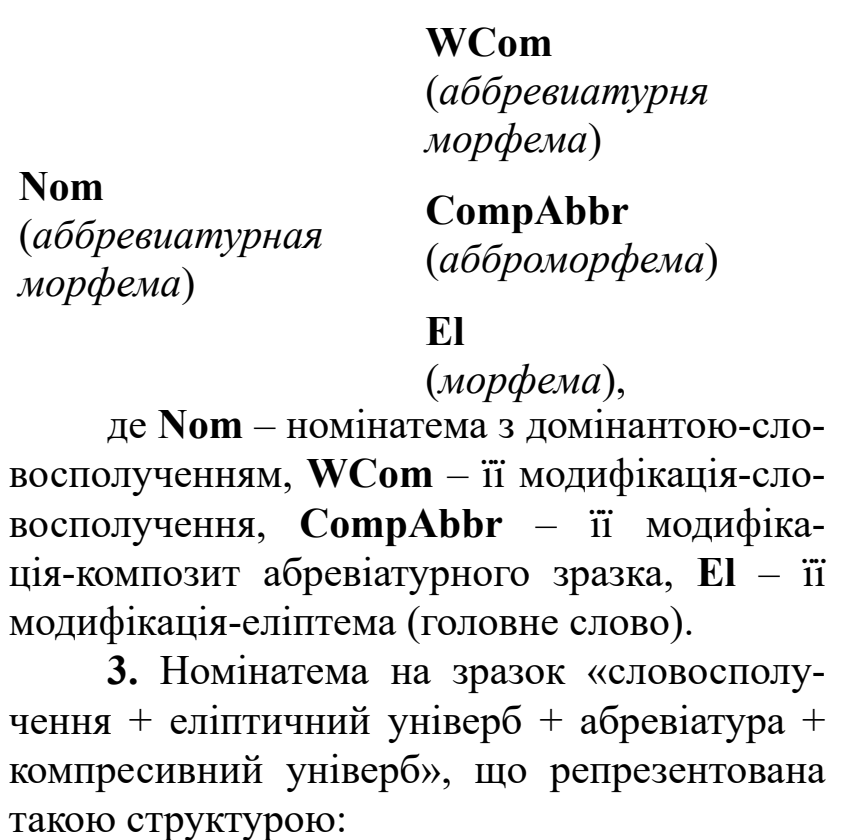

\section{WCom}

(день рождения)

Nom $\mathbf{U}$

(день рождения)

\section{Abre}

(ДР)

\section{ComprU}

(денрик),

$\begin{array}{ll}\text { Nom } & \begin{array}{l}\mathbf{U} \\ (\text { медичка })\end{array} \\ \begin{array}{l}\text { медицинская } \\ \text { сестр) }\end{array} & \begin{array}{l}\text { CompAbbr } \\ (\text { медсестра) }\end{array} \\ & \text { El } \\ & (\text { сестра }),\end{array}$

де Nom - номінатема 3 домінантою-словосполученням, WCom - iї модифікація-словосполучення, $\mathbf{U}$ - iї модифікація-універб, CompAbbr - iii модифікація-композит абревіатурного зразка, El - іiі модифікація-еліптема (головне слово).

6. Номінатема на зразок «словосполучення + еліптичний універб + абревіатура + еліптема (залежне слово)», що репрезентована такою структурою:

\section{NomU}

(наличные деньги)

\section{WCom \\ (наличные деньги) \\ (наличка)}

Abbr
(нал)
El
(наличные),

де Nom - номінатема 3 домінантою-словосполученням, WCom - іiі модифікація-словосполучення, $\mathbf{U}$ - iї модифікація-універб, Abbr - iii модифікація-абревіатура, El - iï модифікація-еліптема (залежне слово).

7. Номінатема на зразок «словосполучення + словосполучення юкстапозитно-абревіатурного зразка + еліптичний універб + еліптема (головне слово)», що репрезентована такою структурою:

\section{WCom}

(детектор лжи)

$\begin{array}{ll}\text { Nom } & \text { Comp } \\ \text { (детектор люи }) & \text { (лжедетектор) } \\ & \text { El } \\ & (\text { детектор) },\end{array}$

де Nom - номінатема 3 домінантою-словосполученням, WCom - іiі модифікація-словосполучення, Comp-iї модифікація-композит, El - iї модифікація-еліптема (головне слово).

5. Номінатема на зразок «словосполучення + еліптичний універб + композит абревіатурного зразка + еліптема (головне слово)», що репрезентована такою структурою:

\section{WCom}

(медицинская

сестра)

\section{WCom}

(микроволновая печь)

Nom $\mathbf{U}$

(микроволновая печь) (микроволнушка)

ComAbbrJukst

(MB-nечb)
El
(печb),

де Nom - номінатема 3 домінантою-словосполученням, WCom - iï модифікація-словосполучення, U - iï модифікація-універб, ComAbbrJukst - iї модифікація-словосполучення юкстапозитно-абревіатурного зразка, El - iii модифікація-еліптема (головне слово).

8. Номінатема на зразок «словосполучення + еліптичний універб + еліптема 
(головне слово)»,що репрезентована такою структурою:

WCom
(оперативная
память)

Nom

(оперативная память)

$\mathbf{U}$

(оперативка)

\section{El}

(память),

де Nom - номінатема 3 домінантою-словосполученням, WCom - іï модифікація-словосполучення, $\mathbf{U}$ - iї модифікація-універб, El - iï модифікація-еліптема (головне слово).

Висновки. Основною номінативною одиницею постає певний інваріант, здатний містити характеристики слова та його форм або характеристики словосполучення та його форм. Найголовнішими критеріями визначення цієї одиниці є ознака номінативності та семантико-граматична тотожність усіх іiі форм незалежно від їхньої різниці за формою та структурою. Ми виокремили вісім структурних різновидів номінатем комплексного зразка, разом з якими загалом наявні чотирнадцять таких типів: 1) словосполучення + абревіатура + еліптичний універб; 2) сло- восполучення + композит + еліптичний універб; 3) словосполучення + словосполучення юкстапозитно-абревіатурного зразка + еліптичний універб; 4) словосполучення + еліптичний універб + еліптема (головне слово) + композит; 5) словосполучення + еліптичний універб + еліптема (залежне слово); 6) словосполучення + композит абревіатурного зразка + абревіатура + еліптичний універб; 7) словосполучення + композит абревіатурного зразка + еліптичний універб + еліптема (головне слово) + абревіатура; 8) словосполучення + композит абревіатурного зразка + еліптема (головне слово); 9) словосполучення + еліптичний універб + абревіатура + компресивний універб; 10) словосполучення + композит + еліптема (головне слово); 11) словосполучення + еліптичний універб + композит абревіатурного зразка + еліптема (головне слово); 12) словосполучення + еліптичний універб + абревіатура + еліптема (залежне слово); 13) словосполучення + словосполучення юкстапозитно-абревіатурного зразка + еліптичний універб + еліптема (головне слово); $14)$ словосполучення + еліптичний універб + еліптема (головне слово). Кожен з цих комплексних інваріантів має власні схеми.

\section{ЛІТЕРАТУРА}

Алпатов В.М. О двух подходах к выделению основных единиц языка. Bопросы языкознания. 1982. № 6. C. 66-74.

Дьячок Н.В. Принципы определения номинатемы комплексного типа. Науково-теоретичний часопис «Мова». Одесса. 2017. № 28. С. 93-98.

Загнітко А.П. Основи українського теоретичного синтаксису. Горлівка : ГДПІІМ, 2003. 228 с.

Теркулов В.И. Слово и номинатема: опыт комплексного описания основной номинативной единицы языка. Горловка : ГГПИИЯ, 2007. 240 с.

Шанский Н.М. Фразеология современного русского языка. Москва : Высшая школа, 1996. 160 с.

Уфимцева Л.Л., Серебреникова Б.Л. Языковая номинация: общие вопросы. Москва : Наука, 1997. $358 \mathrm{c}$.

Jackson H. Words and their Meaning. London and New York : Longman, 1995. 279 p.

\section{REFERENCES}

Alpatov, V.M. (1982). O dvukh podkhodakh k vydeleniyu osnovnykh yedinits yazyka [Two approaches to the definition of the principal language units]. Voprosy yazykoznaniya - Linguistic issues, 6, 66-74 [in Russian].

Diachok, N.V. (2017). Printsipy opredeleniya nominatemy kompleksnogo tipa [Principles of definition of the nominathemes of complex type]. Naukovo-teoretychnyy chasopys "Mova" - Scientific and theoretical journal "Language", 28, 93-98 [in Russian].

Zagnítko, A.P. (2003). Osnovy ukrainskoho teoretychnoho syntaksysu [Foundations of the Ukrainian theoretical syntax]: Gorlívka: GDPÍÍM [in Ukrainian].

Terkulov, V.I. (2007). Slovo i nominatema: opyt kompleksnogo opisaniya osnovnoy nominativnoy yedinitsy yazyka [Word and nominatheme: the experience of a complex description of the main nominative language unit]. Gorlovka : GGPIIY [in Russian]. 
Shanskiy, N. M. (1996). Frazeologiya sovremennogo russkogo yazyka [Phraseology of the modern Russian language]. Moscow : Vysshaya shkola [in Russian].

Ufimtseva, L.L., Serebrenikova, B.L. (1977). Yazykovaya nominatsiya : obshchiye voprosy [Language nomination: general issues]. Moscow: Nauka [in Russian].

Jackson, H. (1995). Words and their Meaning. London and New York : Longman [in English]. 